ZOOLOGIA 32 (4): 321-324, August 2015

http://dx.doi.org/10.1590/S1984-46702015000400008

SHORT COMMUNICATION

\title{
The cuticular profile of the aristiform hair as a characteristic feature of Abrawayaomys (Rodentia: Cricetidae)
}

\author{
Tarcísio de Souza Duarte ${ }^{1,2} \&$ Gisele Lessa ${ }^{1}$
}

\author{
${ }^{1}$ Museu de Zoologia João Moojen, Departamento de Biologia Animal, Universidade Federal de Viçosa. Vila Gianetti 32, \\ 36570-000 Viçosa, MG, Brazil. \\ ${ }^{2}$ Corresponding author. E-mail: tarcisio.sduarte@gmail.com
}

\begin{abstract}
The cuticle is the outermost of the three cellular layers of the mammalian hair. It comprises numerous keratinized scales, whose morphology, combined with other microscopic characteristics of the hair, confers characteristic signature traits to various different species. This study aimed to analyze whether the cuticular patterns of the aristiform hair had any signature implications for the two species of the genus Abrawayaomys Cunha \& Cruz, 1979. We identified the cuticular profiles of $A$. ruschi and A. chebezi. Both species have similar hair pattern. The base of the hair shows "irregular waved" scales with smooth and continuous edges, and the apex showed "transversal waved" smallsized scales with continuous and ornamented edges. The middle portion of the hair exhibits different cuticular patterns on different sides of a single hair follicle: "transversal waved" on the dorsal side and "narrow losangled" on the ventral side. This distribution pattern of the cuticular scales is an unprecedented record for any mammal, and it is an important generic feature that allows the identification of single samples, such as those found in predators' gastrointestinal contents. The species in question are considered rare due to the restricted number of specimens deposited in scientific collections. Our findings may contribute to expanding the species' geographic range by making it possible to identify it in various situations. These results highlight the relevance of studies pertaining the identification of the micromorphology of the aristiform hair, which can be used as a tool to accurately identify rodents.
\end{abstract}

KEY WORDS. Micromorphology; Sigmodontinae; spines; taxonomy; tricology.

A hair is a filamentous epidermal outgrowth characteristic of mammals (Pough et al. 2008). The structure of the hair is polymorphous and many of its characteristics are taxonomically important, since they vary significantly among phylogenetically similar species (CHERNOvA 2002). The basic hair structure comprises three concentric layers of keratinized cells with biochemically distinct compositions (TEerINk 1991). The outermost layer, also called cuticle, is formed by numerous transparent scales resulting from the production and deposition of keratin on the epithelial cells (Meyer et al. 2002, Quadros \& MonteiroFILHo 2006a). The cuticular scales and their diversity of forms have been the subject of many studies (BENEDICT 1957, Moore et al. 1983, Brunner \& Comman 1974, Quadros \& Monteiro-Filho 2006a). Each species or group of species has its own cuticular profile, which, combined with other microscopic features of the hair, enable the rapid identification of biological specimens. This technique has been extensively used in numerous taxonomy and ecology studies (Meng \& Wyss 1997, Peurach 2003, Cavia et al. 2008, SAto et al. 2010, SARKAR et al. 2010, Yates et al. 2010, Martin et al. 2009, Silveira et al. 2013, Vanstreels et al. 2010).
The guard-hair is widely used in the area of trichologyrelated taxonomy. However, there is limited information on the micromorphology of other varieties of hair such as the aristiform hair found in Echimyidae and Cricetidae rodents. Hoey et al. (2004) studied aristiform hairs from Niviventer fulvescens (Gray, 1847), Maxomys surifer (Miller, 1900), Hoplomys gymnurus (Thomas, 1897) and 17 species of Proechimys Allen, 1899, and PARDIÑAs et al. (2009) used aristiform hairs in the identification of Abrawayaomys chebezi. Focusing on the paucity of knowledge about the characteristic features of hair, we conducted this study in order to determine whether cuticular patterns of aristiform hairs of two species of Abrawayaomys Cunha \& Cruz, 1979 are diagnostic features.

We analyzed 75 aristiform hairs from A. ruschii collected from fifteen specimens that were deposited into the mammal collections of the Museu de Zoologia João Moojen at the Universidade Federal de Viçosa (MZUFV - 3562, 3565, 3569), Universidade Federal de Ouro Preto (UFOP - 057R, 058R, 059R, 206R, 326R), Pontifícia Universidade Católica de Minas Gerais (MZPUC/MG - 1874, 1971, 2163, 2157, 2282) and Museu Nacio-

2015 | Sociedade Brasileira de Zoologia | www.sbzoologia.org.br | www.scielo.br/zool All content of the journal, except where identified, is licensed under a Creative Commons attribution-type BY-NC. 
nal at Universidade Federal do Rio de Janeiro, including from the holotype ( $\mathrm{MN}-23075,675572)$. We also observed five hairs from one specimen of $A$. chebezi located at the Museo Argentino de Ciencias Naturales Bernardino Rivadavia (MACN - 20253), Buenos Aires, Argentina. The microscope slides were prepared using the method proposed by Quadros \& Monteiro-Filho (2006b). Accordingly, the hair samples were pressed onto a thin layer of commercial enamel (used for nails) resulting in an imprint of the cuticular scales. The corresponding micromorphologies were carefully studied based on the enamel-generated imprints. Because they are flat, the aristiform hairs were schematically divided into ventral and dorsal sides, and into proximal (near to the hair bulb), middle, and distal (apex) regions. We adopted the nomenclature system proposed by Quadros \& Monteiro-Filho (2006a). The observations and photographs were taken using the Olympus optical (light) microscope AX70 TRF equipped with the U-PHOTO system, and linked to a digital camera (Spot Insightcolour 3.2.0, Diagnostic Instruments Inc.), and a microcomputer with an image capturing software (Zeiss AxioVision).

The not imbricated pattern of the cuticle was observed in all samples. The "irregular waved" scales were observed near the base of the fibers, and they possessed smooth and continuous edges (Fig. 1). The distal portion of the hairs showed "transversal waved" scales with continuous and ornamented edges (Fig. 2). Both these patterns were similar on the ventral and dorsal sides. In the middle portion, we could observe two sides of the same hair showing distinct morphological patterns of cuticular scales. The dorsal surface displayed the "transversal waved" wide scales with continuous and unornamented edges (Fig. 3), whereas the ventral surface exhibited "narrow losangic" patterns (Fig. 4). We refer to this arrangement as "overlapped cuticular" because, two type of scales were visualized simultaneously under the microscopic slides with the hair still attached to the enamel.

This "overlapped cuticular" arrangement on the scales of the middle region is an unprecedented observation for any mammal. While characterizing A. chebezi PARDiÑas et al. (2009) also identified the same patterns, "transversal waved" and "narrow losangic" However, in their results, these patterns occurred in tandem and corresponded only to the characteristic features we found on the dorsal side of the hair. This divergence was probably due to the differences between the methods of preparation and analysis of the hair samples. In the aforementioned study is not clear whether the ventral and dorsal sides of the hairs were individually observed, which we consider fundamental to the analysis of this kind of hair because it is dorsoventraly flat.

There are only few records of Abrawayaomys, which are found in the Atlantic Forest of Brazil in a continuous from the state of Espírito Santo through the states of Rio de Janeiro, Minas Gerais, São Paulo, Paraná, and Santa Catarina, in Brazil, to Argentina in the province of Misiones (Amori \& Gippoliti
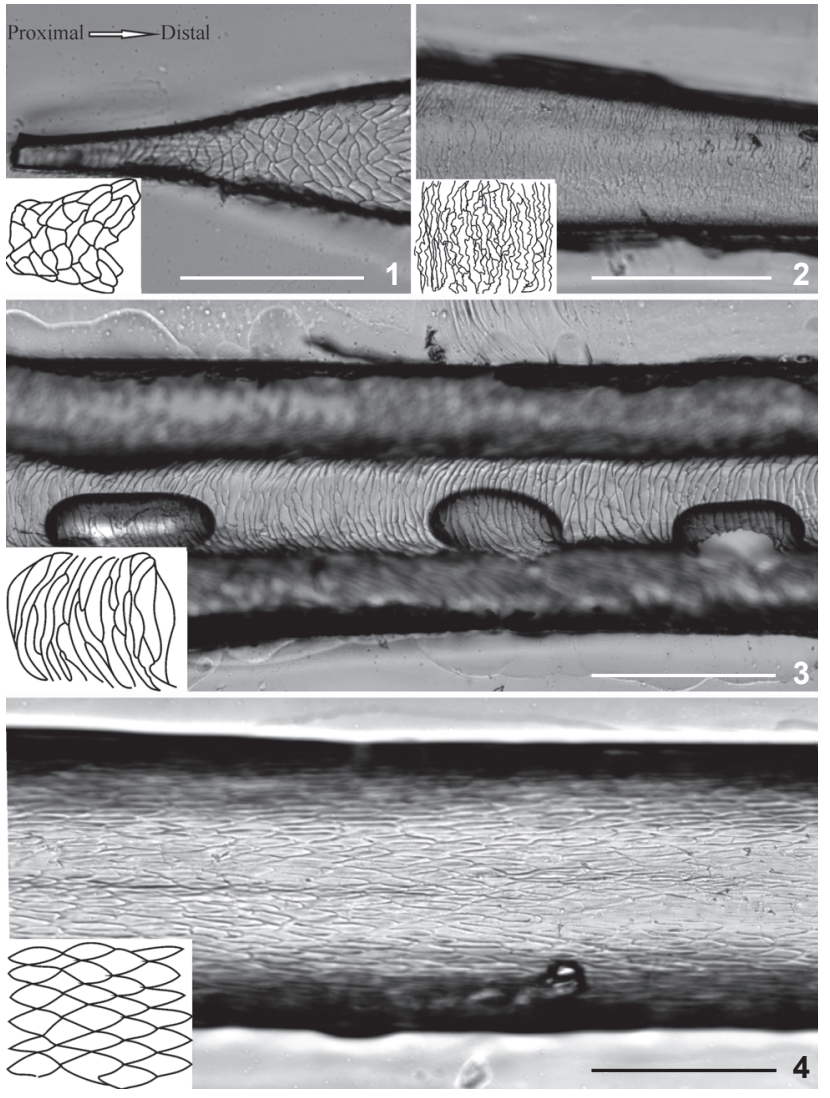

Figures 1-4. Cuticular patterns of the aristiform hair of Abrawayaomys, represented by the cuticle imprinting of $A$. chebezi (MACN 20253): (1-2) proximal and distal patterns, respectively; (3-4) overlapping patterns on the dorsal and ventral sides, respectively. Scal bars: $100 \mu \mathrm{m}$.

2003, Pardiñas et al. 2009, Passamani et al. 2011, Cerboncini et al. 2014, MaEstri et al. 2015). Specimens were captured using live-traps, or and osteological remains were collected from the pellets of owls (PARDIÑAS et al. 2009). Hairs are also found in the gastrointestinal contents of predators quite frequently, and these hair samples were not in any way damaged in their microstructure (Quadros \& Monteiro-Filho 1998). Thus, besides being a novelty, the overlapping cuticular pattern is a characteristic feature of the genus as it allows the species to be identified even when they are not captured alive. Analyzes of hair samples can consequently expand the knowledge on the distribution and ecology of species of sigmodontinae rodents since they are important food items for predators (RосHA et al. 2004, Sousa \& Bager 2008, Rocha-Mendes et al. 2010).

Although the qualitative analysis of the aristiform have not allowed specific identification their characteristics were the same in all specimens and we consider them as diagnostic for the genus. Nevertheless, this absence of variation differs 
from other morphological features of Abrawayaomys, for which PARDIÑAS et al. (2009) indicate a substantial variety of conditions among the specimens from different collection sites, even suggesting the possible existence of a third species. This contrast demonstrates that the analysis of different traits is necessary to elucidate the taxonomy of this group.

\section{ACKNOWLEDGMENTS}

We thank the Fundação de Amparo à Pesquisa de Minas Gerais (FAPEMIG) for the scholarship awarded. Special thanks to Ulysses Pardiñas (Centro Nacional Patagónico), João Oliveira (Museu Nacional, Universidade Federal do Rio de Janeiro), Maria R.S. Pires and Caryne Braga (Universidade Federal de Ouro Preto), Cláudia G. Costa (PUC-Minas) for kindly providing the sample hairs used in the above experiments. Thanks to the Museu de Zoologia João Moojen for their support, to Renata S.A. Meira, coordinator of the Laboratório de Anatomia e Morfologia Vegetal of Universidade Federal de Viçosa, for providing the microscopy equipment and to Pollyanna A. Barros for the suggestions and corrections to the English version of the manuscript.

\section{LITERATURE CITED}

Amori G, Gippolitr S (2003) A Higher taxon approach to rodent conservation priorities for the 21st century. Animal Biodiversity and Conservation 26(2): 1-18.

BENEDICT FA (1957) Hair structure as a generic character in bats. Univeristy of California Publications in Zoology 59: 285548 .

Brunner H, COMAn BJ (1974) The identification of mammalian hair. Melborne, Inkata Press, 176p.

Cavia R, Andrade A, Zamero ME, Fernández MS, Muschetto E, Cueto GR, SuÁrez OV (2008) Hair Structure of small rodents from central Argentina: A tool for species identification. Mammalia 72: 35-43. doi: 10.1515/MAM.2008.009

Cerboncini RaS, Zanata TB, Cunha WL, Rorato aM, Calefi as, Sbeghen MR, Macagnan R, Abreu KC, Ono MA, Passos FC (2014) Distribution extension of Abrawayaomys ruschii Cunha \& Cruz, 1979 (Rodentia, Cricetidae) with the first records in the state of Paraná, southern, Brazil. Check List 10(3): 660-662.

Chernova OF (2002) Architectonic and Diagnostic Significance of Hair Cuticle. Biology Bulletin 29(3): 238-247.

Hoey KA, Wise RR, AdLer GH (2004) Ultrastructure of echimyid and murid rodent spines. Journal of Zoology 263: 307-315.

Maestri R, Kubiak BB, Galiano D, Freitas TRO, Marinho JR (2015) New record and distribution extension of the rare Atlantic Forest endemic Abrawayaomys ruschii Cunha \& Cruz, 1979 (Rodentia, Sigmodontinae). Check List 11(2): 1558.

Martín PS, Gheler-Costa C, Verdade LM (2009) Microestrutura de pelos de pequenos mamíferos não-voadores: chave para identificação de espécies de agroecossistemas do estado de São Paulo, Brasil. Biota Neotropica 9(1): 233-241.

Meng J, Wyss AR (1997) Multituberculate and other mammal hair recovered from paleogene excreta. Nature 385(20): 712714.

Meyer H, Schanapper A, HÜlmann G (2002) The hair cuticle of mammals and its relationship to functions of the hair coat. Journal of Zoology, 256: 489-494. doi: 10.1017/S0952836902000535

Moore DW, Braun JK (1983) Keys to the hairs of the families Soricidae, Vespertilionidae, and Muridae within Tennessee. Journal of the Tennessee Academy of Science, 58(3-4): 40-43.

Pardiñas UfJ, Teta P, D'Elia G (2009) Taxonomy and distribution of Abrawayaomys (Rodentia: Cricetidae), an Atlantic Forest endemic with the description of a new species. Zootaxa 2128: 39-60.

Passamani M, Cerboncini RAS, Oliveira Je (2011) Distribution extension of Phaenomys ferrugineous (Thomas, 1984), and new data on Abrawayaomys ruschii Cunha \& Cruz 1979 and Rhagomys rufescens (Thomas, 1886), three rare species of rodents (Rodentia, Cricetidae) in Minas Gerais, Brasil. Check List 7(6): 827-831.

Peurach SC (2003) High altitude collision an airplane and a hoary Bat, Lasiurus cinereus. Bat Research News 44(1): 2-3.

Pough FH, Heiser JB, Mcfarland WN (2008) A Vida dos Vertebrados. São Paulo, Atheneu, 4th ed., 839p.

Quadros J, Monteiro-Filho ELA (2006a) Coleta e preparação de pelos de mamíferos para identificação em microscopia óptica. Revista Brasileira de Zoologia 23(1): 274-278. doi: 10.1590/S0101-81752006000100022

Quadros J, Monteiro-FilHo ELA (2006b) Revisão conceitual, padrões microestruturais e proposta nomenclatória para pelos-guarda de mamíferos brasileiros. Revista Brasileira de Zoologia 23(1): 279-292. doi: 10.1590/S0101-81752006000100023

Quadros J, Monteiro-Filho ElA (1998) Effects of digestion, putrefaction, and taxidermy processes on Didelphis albiventris hair morphology. Journal of Zoology 244: 331-334.

Rocha-Mendes F, Mikich SB, Quadros J, Pedro WA (2010) Feeding ecology of carnivores (Mammalia, Carnivora) in Atlantic Forest remnants, Southern Brazil. Biota Neotropica 10(4): 1-10. Available online at: http://www.biotaneotropica.org.br/ v10n4/pt/fullpaper?bn00210042010+en

Rocha VJ, Reis NR, Seкiama ML (2004) Diet and seed dispersal by Cerdocyon thous (Linnaeus) (Carnivora, Canidae), in a forest fragment in Paraná. Revista Brasileira de Zoologia 21(4): 871-876. doi: 10.1590/S0101-81752004000400022

SARKAR PS, JK DE, Manna CK (2010) Identification of guard hair of seven species of the family Cercopithecidae (Primates: Mammalia). Proceedings of the Zoological Society 63(2): 121-128.

Sato I, Nakaki S, Murata K, Takeshita H, Mukai T (2010) Forensic hair analysis to identify animal species on a case of pet animal abuse. International Journal of Legal Medicine 124: 249-256. doi 10.1007/s00414-009-0383-2 
Silveira S, Sbalqueiro IJ, ELA Monteiro-Filho (2013) Identificação de espécies brasileiras de Akodon (Rodentia: Cricetidae: Sigmodontinae) através da microestrutura dos pelos. Biota Neotropica 13(1): 339345. Available online at: http://www.biotaneotropica.org.br/v13n1/ pt/fullpaper?bn00713012013+pt

Sousa KS, BAger A (2008) Feeding habits of Geoffroy's cat (Leopardus geoffroyi) in southern Brazil. Mammalian Biology 73(4): 303-308. doi 10.1016/j.mambio.2007.04.001

TEeRINK BJ (1991) Hair of west European mammals: atlas and identification. Cambridge, Cambridge University Press, 224p.
Vanstreels ReT, Ramalho FP, Adania CH (2010) Microestrutura de pêlos-guardas de felídeos brasileiros: Considerações para identificação de espécies. Biota Neotropica 10(1): 333-337. Available online at: http://www.biotaneotropica.org.br/ v10n1/pt/fullpaper?bn00910012010+pt

Yattes BC, Espinoza EO, Baker BW (2010) Forensic species identification of elephant (Elephantidae) and giraffe (Giraffidae) tail hair using light microscopy. Forensic Science, Medicine and Pathology 6(3): 165-171. doi: 10.1007/s12024-010-9169-6

Submitted: 22 October 2014

Received in revised form: 5 February 2015

Accepted: 17 June 2015

Editorial responsibility: Fernando de C. Passos 